\title{
Seasonal variations in gastrointestinal parasites excreted by the gray mouse lemur Microcebus murinus in Madagascar
}

\author{
Brigitte M. Raharivololona ${ }^{1,2, *}$, Jörg U. Ganzhorn ${ }^{2}$ \\ ${ }^{1}$ Département d'Anthropologie et de Biologie Évolutive, Faculté des Sciences, PO Box 906, Université d'Antananarivo, \\ Antananarivo 101, Madagascar \\ ${ }^{2}$ Department of Animal Ecology and Conservation, University of Hamburg, Biozentrum Grindel, Martin-Luther-King Platz 3, \\ 20146 Hamburg, Germany
}

\begin{abstract}
We describe seasonal variations in gastrointestinal parasites found in feces of the gray mouse lemur Microcebus murinus. Our study was carried out in the evergreen littoral forest of Mandena, Madagascar. Fecal samples from M. murinus caught during monthly trapping sessions were screened for eggs and larvae of intestinal parasites. Gastrointestinal parasite infection of $M$. murinus was characterized by parasite species richness, the prevalence of parasites, and the intensity of infection expressed as the number of parasite eggs, larvae, and cysts per $\mathrm{g}$ feces. We used a modification of the McMaster flotation egg counting technique to quantify parasite egg shedding. Parasite excretions changed seasonally when analyzed on the level of individual hosts. The number of parasite species and the abundance of parasite eggs and larvae in Microcebus feces were higher during the hot season than during the cold season. Reduced parasite excretion during the cold season could be due to environmental factors or to the ability of $M$. murinus to enter torpor and hibernation during the cold season, which might lead to reduced metabolism of intestinal parasites and might thus result in reduced shedding of eggs. No such variation was found when the analyses were based on samples of unknown origin.
\end{abstract}

KEY WORDS: Primates $\cdot$ Madagascar $\cdot$ Parasite infection $\cdot$ Torpor $\cdot$ Seasonal variation $\cdot$ Nematoda Cestoda

Resale or republication not permitted without written consent of the publisher

\section{INTRODUCTION}

Madagascar is one of the biodiversity hotspots of the world in urgent need of effective conservation of its unique biota (Mittermeier et al. 2004). Lemurs, the primates of Madagascar, are among the best known taxa of the island. Investigations of the animals' health status are important to improve conservation measures (Dobson 1988, May et al. 1988, Thorne et al. 1988, Nizeyi et al. 1999, 2002a,b, Daszak et al. 2000, Graczyk et al. 2001). Parasitological studies have concentrated on large primates such as apes and monkeys (Stuart \& Strier 1995, Gillespie et al. 2004, 2005, Boesch 2008, Chapman \& Huffman 2009). This is probably due to epidemiological interest because monkeys and apes are genetically closer to humans and are known as a reservoir of certain pests and diseases fatal to humans (and vice versa), such as Ebola and HIV viruses (Wolfe et al. 1998). Prosimian gastrointestinal parasites have received little attention to date. Most studies have focused on parasite inventories and morphological descriptions (e.g. Chabaud \& Choquet 1955, Chabaud \& Larivière 1955, Chabaud \& Brygoo 1956, Chabaud \& Petter 1958, 1959, Chabaud et al. 1961a,b, 1964, 1965, Petter et al. 1972, Hugot et al. 1995, 1996, Hugot 1998, Hugot \& Baylac 2007, Randriamiadamanana 1998, Raharivololona 2006, 2009, Rasambainarivo 2008), with additional information on the occurrence of these parasites in sympatric lemurs and other small mammals (Raharivololona et al. 2007). Irwin \& Raharison (in press) summarize our knowledge of lemur endoparasites in Madagascar in general. 
Parasitological and biomedical studies of lemurs in an ecological context are still in their infancy, and little is known about the effects of changing environmental conditions on parasite infections (e.g. Junge \& Louis 2002, 2005, 2007, Dutton et al. 2003, 2008, Schad et al. 2004, 2005, Junge \& Sauther 2006, Raharivololona et al. 2007, Schwensow et al. 2007, Raharivololona \& Ganzhorn 2009, Wright et al. 2009, Ganzhorn et al. in press, N. Schwitzer et al. unpubl. data). In studies on Microcebus murinus in the littoral forest, lemurs from smaller fragments were parasitized to a higher degree than animals from larger forest fragments. In large forests, degradation of the forest was linked to higher parasite loads. This situation was reversed in small forest fragments (Raharivololona \& Ganzhorn 2009). N. Schwitzer et al. (unpubl. data) report increased intestinal parasite loads in populations of blue-eyed black lemurs Eulemur flavifrons living in degraded habitats, whereas ectoparasite communities of MilneEdwards' sifaka Propithecus edwardsi showed little variation between primary and more degraded rain forest but significant differences between the cool and the hot season (Wright et al. 2009). The same has been reported for nematode infections in other primates (Huffman et al. 1997). Thus, there are seasonal effects either in parasite infections or at least in the excretion of parasites that could be used for diagnostic evalua- tions. However, health surveys of free-living populations often have to be conducted within short periods of time without knowing whether parasite prevalences or infection intensities vary during the course of the year. Therefore, the aim of this study was to document the extent to which the excretion of intestinal parasite larvae and eggs vary over the year in $M$. murinus.

\section{MATERIALS AND METHODS}

Study site. The study was carried out in fragments M5, M13, M15, M16, and M20 of the littoral forest of Mandena, ca. $12 \mathrm{~km}$ northeast of Tolagnaro, at sites ranging in altitude from 0 to $20 \mathrm{~m}$ (Fig. 1). Annual rainfall is about $1600 \mathrm{~mm}$, with considerable fluctuations between years. In 2003, September, October, and November were the months with the lowest rainfall (Fig. 2). June to August are the coldest months (i.e. cold season; Vincelette et al. 2007a).

Study species. Microcebus murinus, the gray mouse lemur, is a small (average weight $60 \mathrm{~g}$ ) nocturnal and omnivorous lemur. In Mandena, its food spectrum consists mainly of fruit, flowers, and insects, and, occasionally, plant exudates. The animals have never been observed to eat reptiles or other vertebrate prey (Lahann 2007). These lemurs forage alone but may form sleep-

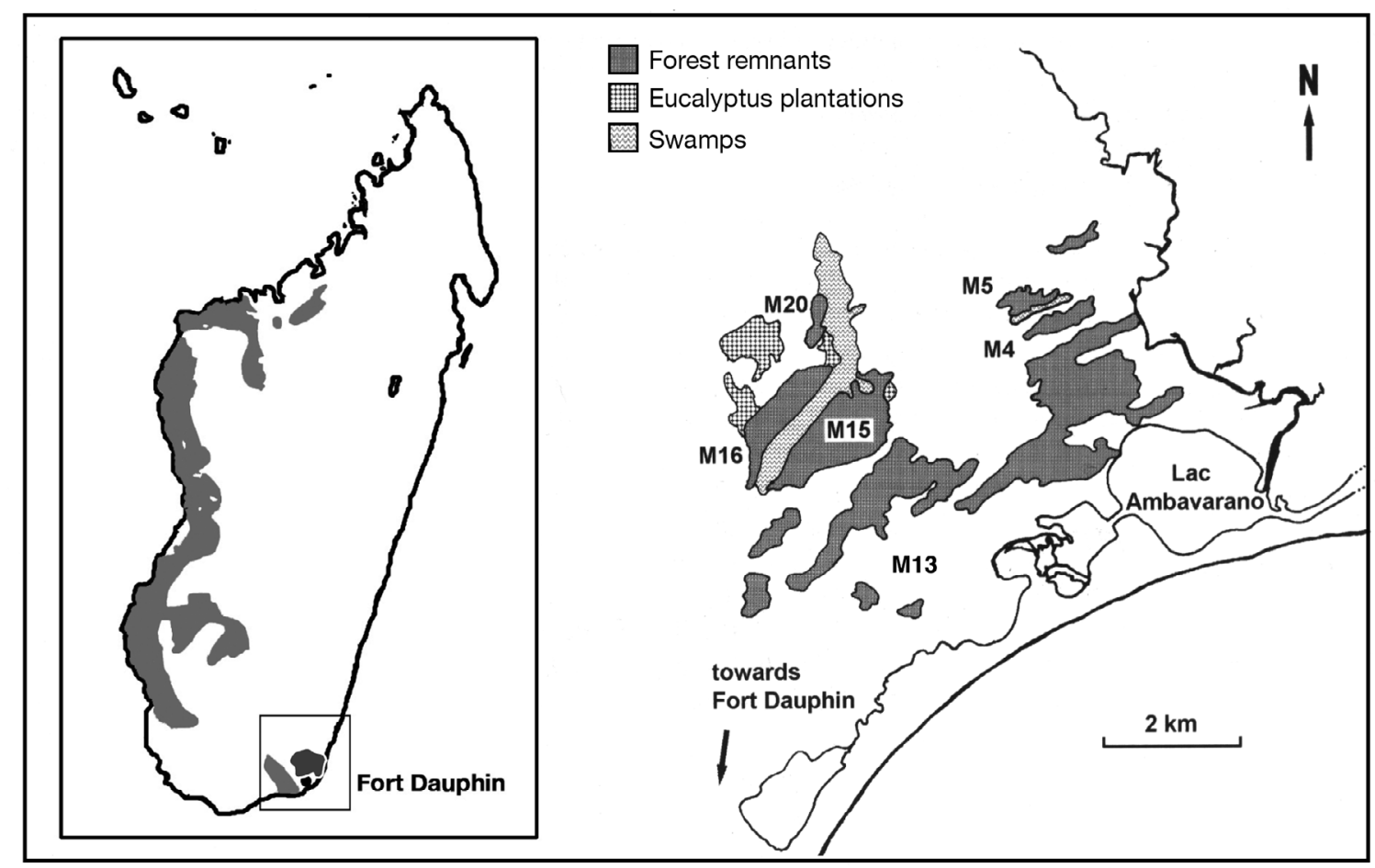

Fig. 1. Study areas in the Tolagnaro region $\left(24^{\circ} 57^{\prime} \mathrm{S}, 47^{\circ} 00^{\prime} \mathrm{E}\right)$ of Madagascar. The forest remnants are numbered and shown as dark shading. Eucalyptus plantations and swamps with bordering Melaleuca (introduced) are also shown (modified from Ramanamanjato \& Ganzhorn 2001). The grey area in the inset marks the distribution of Microcebus murinus on Madagascar (map from R. H. Orozco, Conservation International) 


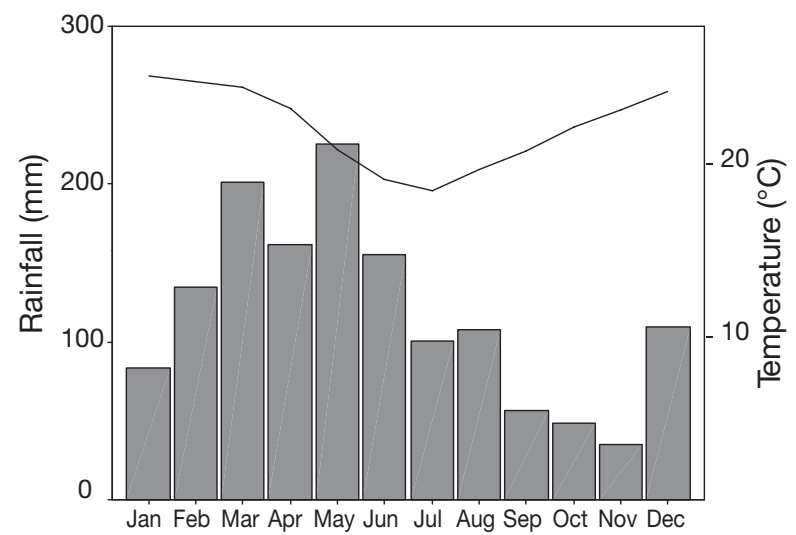

Fig. 2. Monthly rainfall in 2003 (bars) and mean temperatures (solid line; averages from 1989 to 1999; Vincelette et al. 2007a)

ing groups in their daytime sleeping shelters. They are arboreal, polygynous, and distributed throughout western, southern, and southeastern Madagascar. They occur in primary, secondary, and disturbed forest habitats (Martin 1972, Petter et al. 1977, Mittermeier et al. 2006). M. murinus can enter daily torpor or prolonged hibernation during the cold season (Petter-Rousseaux 1980, Ortmann et al. 1996, Schmid \& Ganzhorn 2009).

Animal trapping. Microcebus murinus were captured with Sherman live traps using standard procedures at permanent study sites set up in different forest fragments of Mandena (Ramanamanjato \& Ganzhorn 2001). Traps baited with banana were set for 4 successive nights per month at 40 or 50 localities in each fragment between April and December 2003. Two traps were set at each locality: one on the ground and the other tied to a tree branch at a height of $1.5 \mathrm{~m}$. All trapped animals were sexed, measured, weighed, and marked permanently with subdermal transponders. Animals were released at the locality where they had been captured. Trapping and handling was authorized by permits issued by the Ministère de l'Environnement, des Eaux et Forêts Malgache.

Fecal sampling and gastrointestinal parasites. Fresh feces were collected from traps or handling bags and stored in vials containing $4 \%$ formalin. A modification of the McMaster flotation egg counting technique (Sloss et al. 1994) was applied to analyze egg shedding. Several studies have found this to be a valid method of evaluating worm burdens in several studies (e.g. Gulland et al. 1993, Stear et al. 1995, Paterson et al. 1998, Coltman et al. 1999, Cassinello et al. 2001, Schwensow et al. 2007). For quantitative analyses, 300 $\mathrm{mg}$ of feces were triturated in a beaker with $3 \mathrm{ml}$ of a saturated potassium iodide solution (KI) with a specific weight of $1.5 \mathrm{~g} \mathrm{ml}^{-1}$. The mixture was poured through a tea strainer to eliminate non-digested large particles. The residue in the tea strainer was washed with $1 \mathrm{ml}$ of
KI. The suspension was filled to a volume of $4.5 \mathrm{ml}$ with the KI solution, stirred again, and transferred to both chambers of a McMaster counting chamber with a pipette. The slide was transferred to a microscope and left alone for $5 \mathrm{~min}$ before examination. During this time, eggs, larvae, and cysts floated to the surface of the counting chambers. The slide was then examined with $100 \times$ and $400 \times$ magnification to identify and count all eggs, larvae, and cysts inside the ruled squares. This procedure was developed by Meyer-Lucht (2003) and has been applied successfully in a number of other studies (e.g. Schad et al. 2004, 2005, Meyer-Lucht \& Sommer 2005). Since Microcebus murinus could be infested with parasites from other animals (such as rats, which may also host all parasites found in M. murinus; Raharivololona et al. 2007) or some of the parasites excreted by $M$. murinus could be parasites from their invertebrate prey, precautions were taken to increase the probability that the parasites described were actually parasites of $M$. murinus. Thus, some individuals of $M$. murinus were kept in quarantine for 4 d. Fecal samples were collected each morning and analyzed for parasites. Food passage time was investigated using markers and determined to be $<24 \mathrm{~h}$ in all cases. Therefore, all parasites found in the feces of these animals after the second night were assumed to be genuine parasites of $M$. murinus and not temporary parasites from prey or accidental infections (Raharivololona 2009, Raharivololona \& Ganzhorn 2009). While these precautions might help to separate true from accidental gastrointestinal parasites, we do not have sufficient information yet to know which of the parasites found in the feces of lemurs are of clinical significance (Junge \& Louis 2007, Junge et al. 2008).

To measure the intensity of parasitism, 3 criteria were applied: parasite species richness, prevalence, and intensity of infection. Parasite species richness is the number of parasite species found in fecal material. Infection prevalence is the ratio of infected individuals to the total number of captured animals. The intensity of infection was defined as the number of eggs, larvae, and cysts found in $1 \mathrm{~g}$ of feces (fecal egg count, FEC). This definition deviates from the generally accepted term that includes only eggs, and was used to be consistent with our previous papers (Raharivololona 2007, 2009, Raharivololona \& Ganzhorn 2009) in which we defined FEC as the number of eggs and larvae found in $1 \mathrm{~g}$ of feces of $1 \mathrm{ind}$. This value is obtained by multiplying the number of eggs, larvae, and cysts counted in the 2 chambers of a McMaster cell by 50 (Euzéby 1981).

Data analyses. We performed the analyses on 2 types of datasets. The first analyses were performed at the 'population level.' Here, we used the captures of all individuals in any given month between April and December 2003. If the same individual was caught 
repeatedly in a given month, only data from the first capture were used for analyses. This dataset includes animals caught repeatedly in different months, but also animals caught only once during the study period, and thus represents a mixture of dependent and independent measures. These data are comparable to most studies based on feces of unknown origin. Statistical analyses were performed on a monthly basis if possible. In addition, months were pooled and assigned to different seasons: (1) hot season (April, May, September to December) and cold season (June to August); (2) wet season (April to August, December) and dry season (September to November). For these analyses, we used data only from the fragment M15/M16 because parasite infections differ between fragments of different size and degree of degradation (Raharivololona \& Ganzhorn 2009). We used non-parametric tests (chisquared, Mann-Whitney $U$, and Kruskal-Wallis analysis of variance, Spearman rank correlation) for these analyses.

Second, we performed analyses at the 'individual level.' We restricted these analyses to individuals caught twice: once during the hot season (September to May) and then again in the cold season (June to August). Our sample size did not allow us to distinguish between the hot seasons before or after the cold season, or between the wet season before or after the dry season, respectively. Therefore, we distinguished only 2 categories for each of the 2 environmental variables: cold - hot and wet-dry. Since we analyzed these data on an individual level, we were able to include individuals caught in all forest fragments. To study the seasonal variation of parasite infection in these related samples, we used the McNemar and Wilcoxon matched-pairs signed-ranks test to compare the parasite species richness, prevalence, and the intensity of infection of Microcebus murinus during the hot and cold and the wet and dry season. For illustrations, the FEC was transformed to $\log 10($ FEC+1). Significance levels are 2-tailed. Statistical tests were run with SPSS 9.0.

\section{RESULTS}

\section{Population level: seasonal variation of parasite species richness and their prevalence}

Eight gastrointestinal parasite species were found in 94 fecal samples collected from 56 individual Microcebus murinus (34 females, 20 males, 2 unknown) caught in forest fragment M15/M16 between April and December 2003: 6 nematode species (Subulura sp., another non-identified species of Ascarididae, Trichuris sp., Lemuricola sp., 1 non-identified species of Oxyuridae, and 1 member of Strongylida), 1 cestode species (genus Hymenolepis; a second species of Hymenolepis was not found in fragment M15/M16 but occurred in other fragments; Raharivololona \& Ganzhorn 2009), and 1 species of Coccidia (Raharivololona 2009). Subulura sp. (Ascarididae) was the species with the highest

Table 1. Prevalence (\%) of different gastrointestinal parasite species in Microcebus murinus caught in different months in forest fragment M15/M16 in 2003. N: sample size

\begin{tabular}{|c|c|c|c|c|c|c|c|c|c|c|}
\hline \multirow{2}{*}{$\begin{array}{l}\text { Parasite } \\
\text { species }\end{array}$} & \multirow[b]{2}{*}{$\begin{array}{c}\text { Apr } \\
\mathrm{N}=10\end{array}$} & \multirow[b]{2}{*}{$\begin{array}{c}\text { May } \\
\mathrm{N}=12\end{array}$} & \multirow[b]{2}{*}{$\begin{array}{l}\text { Jun } \\
\mathrm{N}=17\end{array}$} & \multirow[b]{2}{*}{$\begin{array}{l}\text { Jul } \\
\mathrm{N}=7\end{array}$} & \multirow{2}{*}{$\begin{array}{l}\text { Prev } \\
\text { Aug } \\
\mathrm{N}=15\end{array}$} & \multirow{2}{*}{$\begin{array}{c}\text { Ice }(\%) \\
\text { Sep } \\
N=6\end{array}$} & \multirow[b]{2}{*}{$\begin{array}{l}\text { Oct } \\
\mathrm{N}=8\end{array}$} & \multirow[b]{2}{*}{$\begin{array}{l}\text { Nov } \\
\mathrm{N}=14\end{array}$} & \multirow[b]{2}{*}{$\begin{array}{l}\text { Dec } \\
N=5\end{array}$} & \multirow[b]{2}{*}{$\begin{array}{l}\text { Total } \\
\mathrm{N}=94\end{array}$} \\
\hline & & & & & & & & & & \\
\hline \multicolumn{11}{|l|}{ Nemathelminthes } \\
\hline \multicolumn{11}{|l|}{ Ascarididae } \\
\hline Ascarididae sp. 1 & 20 & 25 & 12 & 57 & 20 & 0 & 0 & 0 & 0 & 14 \\
\hline Subulura sp. & 50 & 58 & 29 & 14 & 73 & 83 & 25 & 43 & 60 & 48 \\
\hline Strongylida & & & & & & & & & & \\
\hline $\begin{array}{l}\text { Strongylida sp. } 1 \\
\text { Trichuridae }\end{array}$ & 20 & 8 & 0 & 0 & 20 & 33 & 0 & 0 & 0 & 9 \\
\hline $\begin{array}{l}\text { Trichuris sp. } \\
\text { Oxyuridae }\end{array}$ & 10 & 0 & 0 & 0 & 7 & 17 & 0 & 0 & 0 & 3 \\
\hline Lemuricola sp. & 10 & 0 & 0 & 0 & 13 & 0 & 0 & 0 & 0 & 3 \\
\hline Oxyuridae sp. 1 & 10 & 8 & 18 & 0 & 0 & 0 & 0 & 0 & 0 & 5 \\
\hline All nematode species & 70 & 67 & 41 & 71 & 73 & 83 & 25 & 43 & 60 & 57 \\
\hline Plathelminthes & & & & & & & & & & \\
\hline $\begin{array}{l}\text { Cestoda } \\
\text { Hymenolepididae }\end{array}$ & & & & & & & & & & \\
\hline Hymenolepis sp. 1 & 10 & 17 & 12 & 71 & 53 & 50 & 0 & 0 & 20 & 23 \\
\hline All cestode species & 10 & 17 & 12 & 71 & 53 & 50 & $\mathbf{0}$ & $\mathbf{0}$ & 20 & 23 \\
\hline Protozoa (Coccidia) & 50 & 42 & 24 & 57 & 67 & 33 & $\mathbf{0}$ & 50 & 40 & 42 \\
\hline $\begin{array}{l}\text { All gastrointestinal } \\
\text { parasites }\end{array}$ & 80 & 75 & 65 & 100 & 87 & 83 & 25 & 71 & 60 & 72 \\
\hline
\end{tabular}


prevalence in feces of $M$. murinus (Table 1). Even though we identified some of the forms only to the family or genus level, all forms were assigned to a given morphotype and were considered to represent a single species.

Of the data listed in Tables 1 \& 2, only the monthly prevalence of the undetermined species of Oxyuridae was correlated with rainfall as one of the environmental variables $\left(\mathrm{r}_{\mathrm{s}}=0.76, \mathrm{p}=0.017, \mathrm{n}=9 \mathrm{mo}\right)$.

\section{Population level: seasonal variation of the intensity of infection}

The intensity of infection varied between months for 'all nematode species' (Kruskal-Wallis analysis of variance: $\chi^{2}=16.29, \mathrm{p}=0.04$, df $=8$ ). This is due to fluctuations in Ascarididae sp. 1 and Subulura sp. $\left(\chi^{2}=15.94\right.$, $\mathrm{p}=0.04$ and $\chi^{2}=16.82, \mathrm{p}=0.03$, respectively). The FEC of cestodes, represented by a single species of Hymenolepis sp. 1, also varied between months $\left(\chi^{2}=\right.$ $28.70, \mathrm{p}<0.001)$ as did the number of 'all gastrointestinal parasites' $\left(\chi^{2}=26.5, p=0.001\right.$; Fig. 3$)$.

\section{Individual level: seasonal variation of parasite species richness and infection prevalence within individuals}

Of the 169 different Microcebus murinus caught in the different fragments during the course of the study, 17 ind. were caught in the hot as well as in the cold season. Fecal samples of these 17 ind. were used to assess seasonal changes in occurrence of parasite eggs and larvae in fecal matter in relation to ambient temperature. Nine of these animals were females, and 8 were males. Thus, results were not sex-biased. Of the 169 M. murinus, 15 (9 females, 6 males) were caught in the wet and in the dry season. Fecal samples from these individuals were used to assess differences between the wet and the dry season.

Nine species of parasite were found in the 17 Microcebus murinus feces during the hot, and 7 during the cold season. Lemuricola sp. and Hymenolepis sp. 2 eggs were not observed in the feces during the cold season (Table 3). On average, the number of nematode species found in the feces of the 17 Microcebus murinus individuals was higher during the hot than during the cold season (Wilcoxon test: $z=2.02$; $\mathrm{p}<0.05$ ). The total number of parasite species also differed significantly between the 2 seasons $(z=3.76$; $p<0.001)$. A single mouse lemur was infected by a maximum of 4 parasite species during the hot season and by 3 parasite species during the cold season (Fig. 4). There were no differences in the number of parasite species between the wet and the dry season.

More mouse lemurs were more infected by Subulura sp. and nematodes in general during the hot than during the cold season. For Subulura sp., the prevalence of infection was $70.6 \%$ during the warm season and $23.5 \%$ during the winter. The nematode prevalence was $76.5 \%$ during the hot season against $41.2 \%$ during the cold season (Table 3). No significant differences were found for the other parasite species. The prevalence of parasite taxa found in the 15 Microcebus murinus did not differ between the wet and the dry season for any parasite taxon (Table 3).

\section{Individual level: seasonal variation of the intensity of infection within individuals}

FECs were significantly higher in the hot than the cold season for all parasite taxa except for the FEC of the non-identified species of Ascarididae, those of Hymenolepis sp. 1, and cestodes in general (Wilcoxon test: $z>2.20$; $<<0.05$; Table 4 ). There were no differences between the wet and the dry season.

\section{DISCUSSION}

The excretion of eggs and larval stages of different gastrointestinal parasites varies significantly over the course of the year. This seasonality is blurred when fecal samples from different animals are pooled and the

Table 2. Median number of different gastrointestinal parasite species in Microcebus murinus caught in different months in forest fragment M15/M16 in 2003. N: sample size

\begin{tabular}{|c|c|c|c|c|c|c|c|c|c|c|}
\hline Month & $\begin{array}{c}\text { Apr } \\
\mathrm{N}=10\end{array}$ & $\begin{array}{c}\text { May } \\
\mathrm{N}=12\end{array}$ & $\begin{array}{c}\text { Jun } \\
\mathrm{N}=17\end{array}$ & $\begin{array}{c}\text { Jul } \\
\mathrm{N}=7\end{array}$ & $\begin{array}{c}\text { Aug } \\
\mathrm{N}=15\end{array}$ & $\begin{array}{c}\text { Sep } \\
N=6\end{array}$ & $\begin{array}{c}\text { Oct } \\
\mathrm{N}=8\end{array}$ & $\begin{array}{c}\text { Nov } \\
\mathrm{N}=14\end{array}$ & $\begin{array}{c}\text { Dec } \\
N=5\end{array}$ & $\begin{array}{c}\text { Total } \\
\mathrm{N}=94\end{array}$ \\
\hline Nemathelminthes & 1 & 1 & 0 & 1 & 1 & 1.5 & 0 & 0 & 1 & 1 \\
\hline Plathelminthes & 0 & 0 & 0 & 1 & 1 & 0.5 & 0 & 0 & 0 & 0 \\
\hline $\begin{array}{l}\text { All gastrointestinal } \\
\text { parasites } \\
\text { (includes Coccidia) }\end{array}$ & 2 & 1 & 1 & 2 & 2 & 2.5 & 0 & 1 & 2 & 1 \\
\hline
\end{tabular}



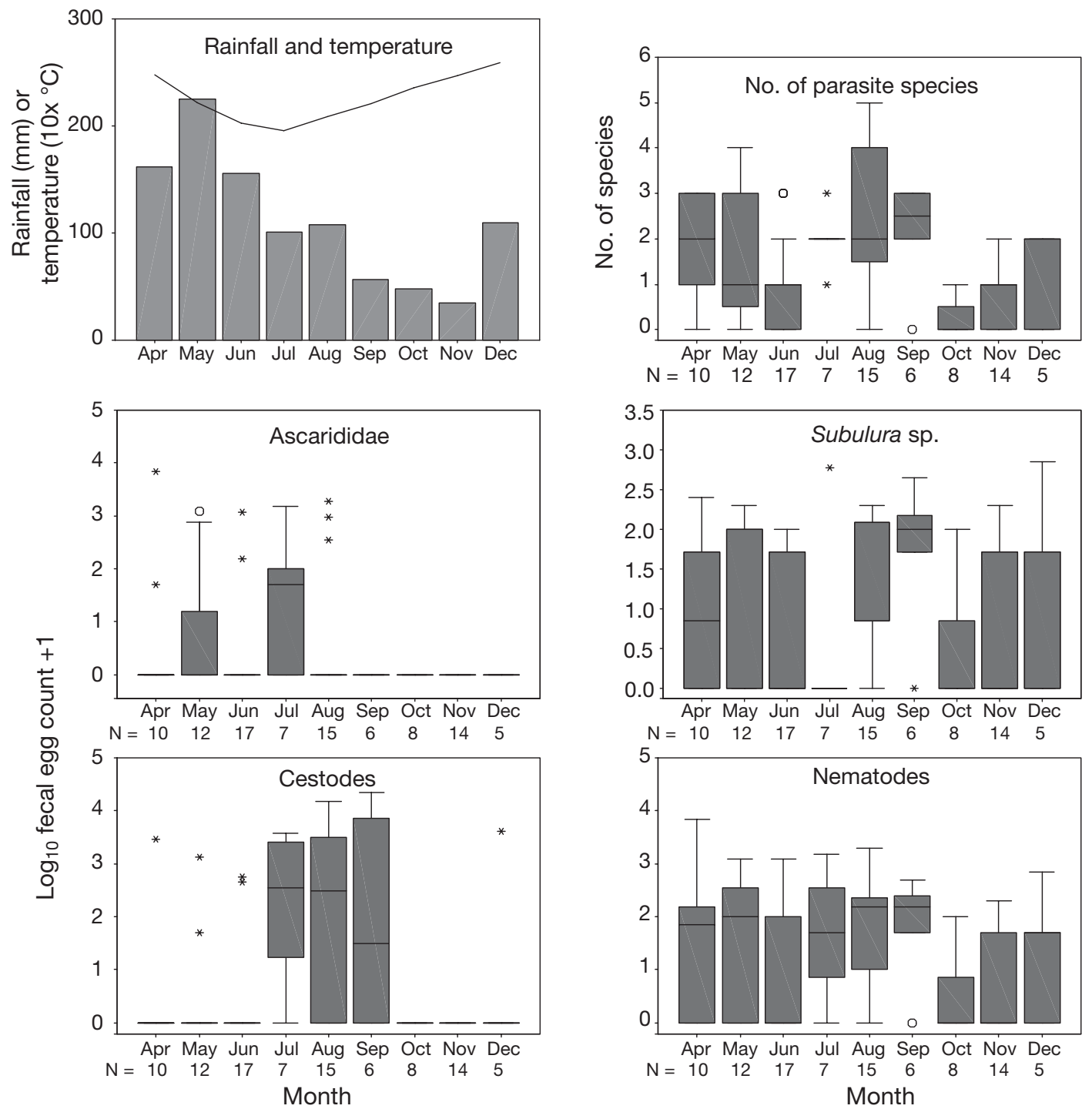

Fig. 3. Monthly variation of the fecal egg count (FEC) for intestinal parasites. Rainfall and temperature data represent a subset of Fig. 2. The numbers on the $x$-axis indicate monthly sample size and months. Median, quartiles and ranges are shown. Asterisks represent extreme values. Circles indicate outliers according to SPSS criteria; these may represent real values, but based on theoretical considerations of natural distributions, but may also represent measurement errors. In some cases, quartiles and min./max. values coincide

same animals are represented in the samples to varying degrees. Also, parasite sheddings tend to be sex biased, with more eggs and larvae found in feces of Microcebus males (Raharivololona et al. 2007). This is a standard problem of unbalanced repeated measures which does not need to be discussed further. Yet, in many cases, field work has to rely on this type of data. Our data do not allow us to analyze these aspects further and to go beyond anecdotal evidence and speculations.

When sampling and analyses can be based on repeated samples of known individuals, a much clearer pattern emerges. In the evergreen littoral forest, parasite-egg shedding in Microcebus murinus seems unaffected by rainfall patterns but shows pronounced and consistent differences between the hot and the cold season. The higher degree of parasite infections of $M$. murinus during the hot season seems to be a general phenomenon that has also been described for ectoparasites in Propithecus edwardsi (Wright et al. 2009), gastrointestinal parasites in Eulemur flavifrons (N. Schwitzer et al. unpubl. data), and gastrointestinal parasites in other primates (Huffman et al. 1997). High ambient temperatures and humid conditions favor hatching of parasite eggs, which increases the abundance of larvae ready to infect the next host (Rogers \& Sommerville 1963, Larsen \& Roepstorff 1999). The majority of intestinal parasites infecting $M$. murinus in the Mandena forest are nematodes with a direct life 
Table 3. Prevalence (\%) of gastrointestinal parasites in the feces of the 17 Microcebus murinus caught during the hot and in the cold season and of 15 ind. caught during the wet and the dry season. Significant differences between seasons are indicated by ${ }^{*}(\mathrm{McNemar}$ tests, $\mathrm{p}<0.05)$. N: sample size

\begin{tabular}{|c|c|c|c|c|}
\hline Taxon & $\begin{array}{c}\text { Hot } \\
\text { season } \\
\mathrm{N}=17\end{array}$ & $\begin{array}{c}\text { Cold } \\
\text { season } \\
\mathrm{N}=17\end{array}$ & $\begin{array}{c}\text { Wet } \\
\text { season } \\
\mathrm{N}=15\end{array}$ & $\begin{array}{c}\text { Dry } \\
\text { season } \\
\mathrm{N}=15\end{array}$ \\
\hline \multicolumn{5}{|l|}{ Nemathelminthes } \\
\hline Ascarididae & & & & \\
\hline Ascarididae sp.1 & 17.6 & 11.8 & 6.7 & 0 \\
\hline Subulura sp. & $70.6^{*}$ & 23.5 & 33.3 & 66.7 \\
\hline Strongylida & & & & \\
\hline $\begin{array}{l}\text { Strongylida sp.1 } \\
\text { Trichuridae }\end{array}$ & 11.8 & 11.8 & 13.3 & 13.3 \\
\hline $\begin{array}{l}\text { Trichuris sp. } \\
\text { Oxyuridae }\end{array}$ & 5.9 & 5.9 & 6.7 & 6.7 \\
\hline Lemuricola sp. & 5.9 & 0 & 0 & 6.7 \\
\hline Oxyuridae sp.1 & 11.8 & 5.9 & 0 & 0 \\
\hline All nematode species & $76.5^{*}$ & 41.2 & 46.7 & 66.7 \\
\hline Plathelminthes & & & & \\
\hline Cestoda & & & & \\
\hline Hymenolepididae & & & & \\
\hline Hymenolepis sp.1 & 23.5 & 29.4 & 26.7 & 20.0 \\
\hline Hymenolepis sp.2 & 11.8 & 0 & 0 & 6.7 \\
\hline All cestode species & 35.3 & 29.4 & 26.7 & 26.7 \\
\hline Protozoa (Coccidia) & 64.7 & 35.3 & 53.3 & 26.7 \\
\hline $\begin{array}{l}\text { All gastrointestinal } \\
\text { parasites }\end{array}$ & 88.2 & 70.6 & 66.7 & 66.7 \\
\hline
\end{tabular}

cycle such as the Ascarididae species, the member of Strongylida, and Trichuris sp. In contrast, Lemuricola sp., another Oxyuridae species, and Subulura sp. have an indirect life cycle with insects as intermediate hosts (reviewed by Irwin \& Raharison in press). The parasite development in these insect hosts is also faster at higher temperatures (Pascual et al. 2006). Due to the general nature of this phenomenon (Taraschewski

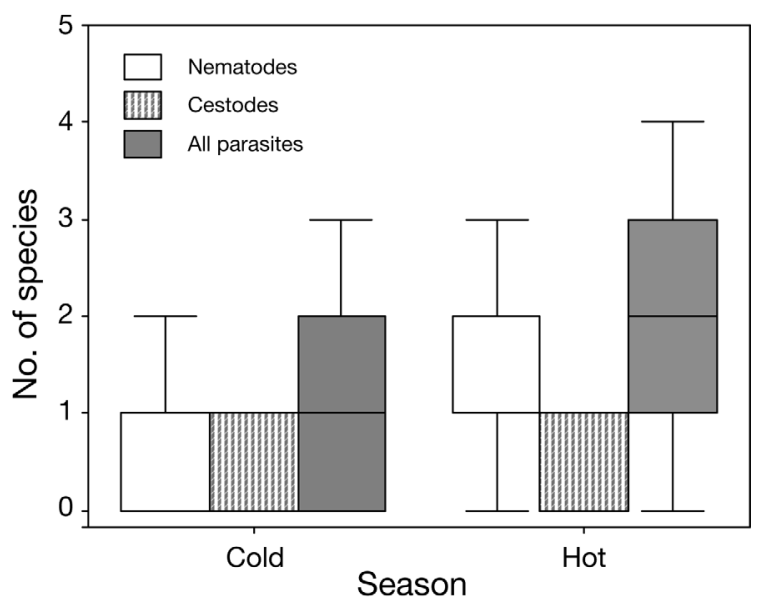

Fig. 4. Seasonal fluctuation in the number of parasite species between the hot and the cold season (median, quartiles, minimum, maximum) found in fecal material of 17 Microcebus murinus

Table 4. Numbers of parasite eggs, larvae, and coccidian cysts (fecal egg count, FEC) found in $1 \mathrm{~g}$ of feces (log $\left.\mathrm{g}_{10} \mathrm{FEC}+1\right)$ of 17 Microcebus murinus during the hot and the cold season and of 15 ind. caught during the wet and the dry season. Values are medians; ranges in parentheses. Significant differences between seasons are indicated by * (Wilcoxon matched-pairs signed ranks tests, $\mathrm{p}<0.05)$. N: sample size

\begin{tabular}{|c|c|c|c|c|}
\hline Taxon & $\begin{array}{c}\text { Hot season } \\
\mathrm{N}=17\end{array}$ & $\begin{array}{l}\text { Cold season } \\
\quad \mathrm{N}=17\end{array}$ & $\begin{array}{l}\text { Wet season } \\
\quad \mathrm{N}=15\end{array}$ & $\begin{array}{l}\text { Dry season } \\
\quad \mathrm{N}=15\end{array}$ \\
\hline \multicolumn{5}{|l|}{ Nemathelminthes } \\
\hline \multicolumn{5}{|l|}{ Ascarididae } \\
\hline Ascarididae sp.1 & $0(0-3.16)$ & $0(0-3.18)$ & $0(0-3.18)$ & $0(0-0)$ \\
\hline Subulura sp. & $2.00\left(0-2.65^{*}\right)$ & $0(0-2.0)$ & $0(0-2.85)$ & $2.00(0-2.65)$ \\
\hline \multicolumn{5}{|l|}{ Strongylida } \\
\hline Strongylida sp.1 & $0\left(0-2.40^{*}\right)$ & $0(0-1.71)$ & $0(0-2.4)$ & $0(0-1.71)$ \\
\hline \multicolumn{5}{|l|}{ Trichuridae } \\
\hline $\begin{array}{l}\text { Trichuris sp. } \\
\text { Oxyuridae }\end{array}$ & $0\left(0-2.18^{*}\right)$ & $0(0-2.0)$ & $0(0-1.71)$ & $0(0-2.18)$ \\
\hline Lemuricola sp. & $0\left(0-1.71^{*}\right)$ & $0(0-0)$ & 0 & $0(0-1.71)$ \\
\hline Oxyuridae sp.1 & $0\left(0-2.18^{*}\right)$ & $0(0-1.71)$ & 0 & 0 \\
\hline All nematode species & $2.00\left(0-3.20^{*}\right)$ & $0(0-3.18)$ & $0(0-3.18)$ & $2.00(0-2.70)$ \\
\hline \multicolumn{5}{|l|}{ Plathelminthes } \\
\hline \multicolumn{5}{|l|}{ Cestoda } \\
\hline \multicolumn{5}{|l|}{ Hymenolepididae } \\
\hline Hymenolepis sp.1 & $0(0-4.35)$ & $0(0-3.54)$ & $0(0-3.47)$ & $0(0-4.35)$ \\
\hline Hymenolepis sp.2 & $0\left(0-3.20^{*}\right)$ & 0 & 0 & $0(0-3.20)$ \\
\hline All cestode species & $0(0-4.35)$ & $0(0-3.57)$ & $0(0-3.47)$ & $0(0-4.35)$ \\
\hline Protozoa (Coccidia) & $1.71\left(0-5.25^{*}\right)$ & $0(0-3.60)$ & $1.71(0-5.25)$ & $0(0-3.81)$ \\
\hline $\begin{array}{l}\text { All gastrointestinal } \\
\text { parasites }\end{array}$ & $2.74\left(0-5.25^{*}\right)$ & $2.65(0-3.60)$ & $2.93(0-5.25)$ & $2.00(0-4.36)$ \\
\hline
\end{tabular}


2006), Chapman et al. (2005) suggested that the prevalence of many parasites will increase at sites where global warming becomes effective, thus matching the phenomenon observed for many human parasites (Martens 1999, Pascual et al. 2006).

In addition to warm temperature effects, which speed up the life cycle of parasites during the hot season, the diet of Microcebus murinus might also contribute to changes in parasite loads. Mouse lemurs feed intensively on invertebrates when available, for example during the hot season (Mittermeier et al. 2006). Subulura sp. is the most common and prevalent nematode in this lemur population. Insects are intermediate hosts for eggs of Subulura sp. where the eggs hatch and develop into larvae that are then ingested by insect-feeding Microcebus (Chabaud \& Larivière 1955, Irwin \& Raharison in press). Thus, it is not surprising that this parasite species is found in higher frequencies in the mouse lemur population during the hot season.

These seasonal changes might be reinforced by the metabolic peculiarities of mouse lemurs. Microcebus murinus go into torpor and enter hibernation during the cold season (Petter-Rousseaux 1980, Ortmann et al. 1996, Schmid \& Ganzhorn 2009, Kobbe \& Dausmann 2009, Dausmann in press). During these periods of reduced metabolism, the body temperature of Microcebus can decrease to $<10^{\circ} \mathrm{C}$. This hypometabolism will slow down parasite metabolism and parasite reproduction in the mammalian host. Thus, even though parasite excretion seems to differ between parasite species as well as between different host species, seasonal variation should be taken into account in parasitological studies.

Acknowledgements. This study was conducted under the Accord de Collaboration between the Université d'Antananarivo (Département de Biologie Animale and Département d'Anthropologie et de Biologie Évolutive) and Hamburg University. It is part of the biodiversity assessment and environmental impact studies of the littoral forest fragments initiated by QIT Madagascar Minerals (QMM). We thank R. Ernest, P. Lahann, N. Rüdel, J. Schüller, and B. Siemers for help with the fieldwork; M. Vincelette, J. B. Ramanamanjato, and their environmental and conservation team as well as other staff of QMM for technical assistance and help with logistics; S. Sommer, J. Axtner, Y. Meyer-Lucht, and N. Schwensow (now at the Institute for Zoo and Wildlife Research, Berlin), and the staff at the Department of Animal Ecology and Conservation, Hamburg University; F. Ariey and the Malaria Department of the Institut Pasteur de Madagascar; Rakotondravao, G. Randrianarivo, and the Département de Recherches Zootechniques et Vétérinaires/FOFIFA for help and assistance in the laboratory analyses. We also thank D. W. Büttner (Bernhard Nocht Institute, Hamburg), A. G. Chabaud, O. Bain, M. C. Durette-Desset, J. P. Hugot (Muséum National d'Histoire Naturelle, Paris), T. R. Gillespie (Department of Zoology, Florida State University), D. Modrý (Department of Parasitology, University of Veterinary and Pharmaceutical Sciences, Czech Republic), and anonymous reviewers for their advice.
This study was funded by the Margot Marsh Biodiversity Foundation, QMM, the German Research Foundation (DFG, Ga 342/14), and the German Academic Exchange Service (DAAD).

\section{LITERATURE CITED}

Boesch C (2008) Why do chimpanzees die in the forest? The challenges of understanding and controlling for wild ape health. Am J Primatol 70:722-726

Cassinello J, Gomendio M, Roldan ERS (2001) Relationship between coefficient of inbreeding and parasite burden in endangered gazelles. Conserv Biol Pract 15:1171-1174

Chabaud AG, Brygoo ER (1956) Description de Rictularia lemuri n. sp. (Nematoda: Thelaziidae). Mem Inst Sci Madag Ser A 11:43-49

Chabaud AG, Choquet MT (1955) Deux nématodes parasites de lémurien. Ann Parasitol 30:329-338

Chabaud AG, Larivière M (1955) Cycle évolutif d'un ascaride: Subulura jacchi (Marcel, 1857) parasite de primates, chez la blatte Blabera fusca. C R Soc Biol 149:1416-1419

Chabaud AG, Petter AJ (1958) Les nematodes parasites de lémuriens malgaches. I. Mem Inst Sci Madag Ser A 12: $139-158$

Chabaud AG, Petter AJ (1959) Les nematodes parasites de lémuriens malgaches. II. Un nouvel oxyure: Lemuricola contagiosus. Mem Inst Sci Madag Ser A 13:127-132

Chabaud AG, Brygoo ER, Petter AJ (1961a) Les nématodes parasites de lémuriens malgaches. IV. Description de deux nouveaux genres et observations sur Protofilaria furcata Chandler. Bull Mus Natl Hist Nat 2e Ser 33:532-544

Chabaud AG, Petter AJ, Golvan Y (1961b) Les nématodes parasites de lémuriens malgaches. III. Collection récoltée par M. et Mme. Francis Petter. Ann Parasitol 36:113-126

Chabaud AG, Brygoo ER, Petter AJ (1964) Les nématodes parasites de lémuriens malgaches. V. Nématodes de Daubentonia madagascariensis. Vie Milieu (Suppl 17): 205-212

Chabaud AG, Brygoo ER, Petter AJ (1965) Les nématodes parasites de lémuriens malgaches. VI. Description de six espèces nouvelles et conclusions générales. Ann Parasitol 40:181-214

Chapman C, Huffman MA (2009) Primates and their parasites. Cambridge University Press, Cambridge

Chapman CA, Gillespie TR, Speirs ML (2005) Parasite prevalence and richness in sympatric colobines: effects of host density. Am J Primatol 67:259-266

Coltman DW, Pilkington JG, Smith JA, Pemberton JM (1999) Parasite-mediated selection against inbred Soay sheep in a free-living, island population. Evolution 53: 1259-1267

Daszak P, Cunningham AA, Hyatt AD (2000) Emerging infectious diseases of wildlife - threats to biodiversity and human health. Science 287:443-449

Dausmann K (in press) An (opposable) thumbs-up for hibernation-hypometabolism in primates. In: Masters $\mathrm{J}$, Gamba M, Génin F (eds) Leaping ahead: advances in prosimian biology. Springer, New York

Dobson AP (1988) The population biology of parasite-induced changes in host behavior. Q Rev Biol 63:139-165

Dutton CJ, Junge RE, Louis EE Jr (2003) Biochemical evaluation of free-ranging ring-tailed lemurs (Lemur catta) in Tsimanampetsotsa Strict Nature Reserve, Madagascar. J Zoo Wildl Med 34:16-24

> Dutton CJ, Junge RE, Louis EE Jr (2008) Biomedical evaluation of free-ranging red ruffed lemurs (Varecia variegata) 
within the Masoala National Park, Madagascar. J Zoo Wildl Med 39:76-85

Euzéby J (1981) Diagnostic expérimental des Helminthoses animales. Ministère de l'Agriculture, Paris

Ganzhorn JU Hapke A, Raharivololona BM, Ramanamanjato JB, Schmid J, Sommer S (in press) Population genetics, parasitism and long-term population dynamics of Microcebus murinus in littoral forest fragments of south-eastern Madagascar. In: Masters J, Gamba M, Génin F (eds) Leaping ahead: advances in prosimian biology. Springer, New York

Gillespie TR, Greiner EC, Chapman CA (2004) Gastrointestinal parasites of the guenons of western Uganda. J Parasitol 90:1356-1360

Gillespie TR, Greiner EC, Chapman CA (2005) Gastrointestinal parasites of the colobus monkeys of Uganda. J Parasitol 91:569-573

Graczyk TK, DaSilva AJ, Cranfield MR, Nizeyi JB, Kalema G, Pieniazek NJ (2001) Cryptosporidium parvum genotype 2 infections in free-ranging mountain gorillas (Gorilla gorilla beringei) of the Bwindi Impenetrable National Park, Uganda. Parasitol Res 87:368-370

Gulland FMD, Albon SD, Pemberton JM, Moorcroft PR, Clutton-Brock TH (1993) Parasite associated polymorphism in a cyclic ungulate population. Proc R Soc Lond B 254:7-13

Huffman MA, Gotoh S, Turner LA, Hamai M, Yoshida K (1997) Seasonal trends in intestinal nematode infection and medical plant use among chimpanzees in the Mahale Mountains, Tanzania. Primates 38:111-125

Hugot JP (1998) Phylogeny of neotropical monkeys: the interplay of morphological molecular, and parasitological data. Mol Phylogenet Evol 9:408-413

Hugot JP, Baylac M (2007) Shape patterns of genital papillae in pinworms (Enterobiinae, Oxyurida, Nematoda) parasite of primates: a landmark analysis. Infect Genet Evol 7: 168-179

Hugot JP, Morand S, Gardner SL (1995) Morphology and morphometrics of three oxyurids parasitic in primates with a description of Lemuricola microcebi n. sp. Int J Parasitol 25:1065-1075

Hugot JP, Gardner SL, Morand S (1996) The Enterobiinae subfam. nov. (Nematoda, Oxyurida) pinworm parasites of primates and rodents. Int J Parasitol 26:147-159

Irwin MT, Raharison JL (in press) A review of the endoparasites of the lemurs of Madagascar. Malagasy Nature

Junge RE, Louis EE (2002) Medical evaluation of free-ranging primates in Betampona Reserve, Madagascar. Lemur News 7:23-25

Junge RE, Louis EE (2005) Preliminary biomedical evaluation of wild ruffed lemurs (Varecia variegata and V. rubra). Am J Primatol 66:85-94

Junge RE, Louis EE Jr (2007) Biomedical evaluation of black lemurs (Eulemur macaco macaco) in Lokobe Reserve, Madagascar. J Zoo Wildl Med 38:67-76

Junge RE, Sauther ML (2006) Overview on the health and disease ecology of wild lemurs: conservation implications. In: Gould L, Sauther ML (eds) Lemurs: ecology and adaptation. Springer, New York, p 423-440

Junge RE, Dutton CJ, Knightly F, Williams CV, Rasambainarivo FT, Louis EE (2008) Comparison of biomedical evaluation for white-fronted brown lemurs (Eulemur fulvus albifrons) from four sites in Madagascar. J Zoo Wildl Med 39:567-575

Kobbe S, Dausmann KH (2009) Hibernation in Malagasy mouse lemurs as a strategy to counter environmental challenge. Naturwissenschaften 96:1221-1227
Lahann P (2007) Feeding ecology and seed dispersal of sympatric cheirogaleid lemurs (Microcebus murinus, Cheirogaleus medius, Cheirogaleus major) in the littoral rainforest of south-east Madagascar. J Zool 271:88-98

Larsen MN, Roepstorff A (1999) Seasonal variation in development and survival of Ascaris suum and Trichuris suis eggs on pastures. Parasitology 119:209-220

Martens P (1999) How will climate change affect human health? Am Sci 87:534-541

Martin RD (1972) Behaviour and ecology of nocturnal Prosimians. Z Tierpsychol (Beiheft 9):43-89

May B, Moody DB, Stebbins WC (1988) The significant features of Japanese macaque coo sounds: a psychophysical study. Anim Behav 36:1432-1444

Meyer-Lucht Y (2003) Einfluss von Verstädterung auf Populationsstruktur, genetische Variabilität und Parasitenbefall bei der Gelbhalsmaus (Apodemus flavicollis). Diploma thesis, Universität Hamburg

Meyer-Lucht Y, Sommer S (2005) MHC diversity and the association to nematode parasitism in the yellow-necked mouse (Apodemus flavicollis). Mol Ecol 14:2233-2243

Mittermeier RA, Gil P, Hoffmann M, Pilgrim J and others (2004) Hotspots revisited. CEMEX, Mexico City

Mittermeier RA, Konstant WR, Hawkins F, Louis EE and others (2006) Lemurs of Madagascar, 2nd edn. Conservation International, Washington, DC

Nizeyi JB, Mwebe R, Nanteza A, Cranfield MR, Kalema GR, Graczyk TK (1999) Cryptosporidium sp. and Giardia sp. infections in mountain gorillas (Gorilla gorilla beringei) of the Bwindi Impenetrable National Park, Uganda. J Parasitol 85:1084-1088

- Nizeyi JB, Cranfield MR, Graczyk TK (2002a) Cattle near the Bwindi Impenetrable National Park, Uganda, as a reservoir of Cryptosporidium parvum and Giardia duodenalis for local community and free-ranging gorillas. Parasitol Res 88:380-385

Nizeyi JB, Sebunya D, da Silva AJ, Cranfield MR, Pieniazek NJ, Graczyk TK (2002b) Cryptosporidiosis in people sharing habitats with free-ranging mountain gorillas (Gorilla gorilla beringei), Uganda. Am J Trop Med Hyg 66:442-444

Ortmann S, Schmid J, Ganzhorn JU, Heldmaier G (1996) Body temperature and torpor in a Malagasy small primate, the mouse lemur. In: Geiser F, Hulbert AJ, Nicol SC (eds) Adaptations to the cold: the 10th International Hibernation Symposium. University of New England Press, Armidale, NSW, p 55-61

- Pascual M, Ahumada JA, Chaves LF, Rodó X, Bouma M (2006) Malaria resurgence in the East African highlands: temperature trends revisited. Proc Natl Acad Sci USA 103:5829-5834

Paterson S, Wilson K, Pemberton JM (1998) Major histocompatibility complex variation associated with juvenile survival and parasite resistance in a large unmanaged ungulate population (Ovis aries L.). Evolution 95:3714-3719

Petter AJ, Chabaud AG, Delavenay R, Brygoo ER (1972) Une nouvelle espèce de nématode du genre Lemuricola, parasite de Daubentonia madagascariensis Gmelin, et considérations sur le genre Lemuricola. Ann Parasitol Hum Comp 47:391-398

Petter JJ, Albignac R, Rumpler Y (1977) Mammifères: lémuriens (primates prosimiens) In: ORSTOM-CNRS (eds) Faune de Madagascar 44. ORSTOM-CNRS, Paris

Petter-Rousseaux A (1980) Seasonal activity rhythms, reproduction, and body weight variations in five sympatric nocturnal prosimians, in simulated light and climatic conditions. In: Charles-Dominique $\mathrm{P}$, Cooper HM, Hladik A, 
Hladik CM and others (eds) Nocturnal Malagasy primates: ecology, physiology, and behavior. Academic Press, New York, p 137-152

Raharivololona BM (2006) Gastrointestinal parasites of Cheirogaleus spp. and Microcebus murinus in the littoral forest of Mandena, Madagascar. Lemur News 11:31-35

Raharivololona BM (2009) L'infestation parasitaire de Microcebus murinus de la forêt littorale de Mandena, Madagascar. Madag Conserv Dev 4:52-62

Raharivololona BM, Ganzhorn JU (2009) Gastrointestinal parasite infection of the gray mouse lemur (Microcebus murinus) in the littoral forest of Mandena, Madagascar: effects of forest fragmentation and degradation. Madag Conserv Dev 4:103-112

Raharivololona BM, Rakotondravao, Ganzhorn JU (2007) Gastrointestinal parasites of small mammals in the littoral forest of Mandena. In: Ganzhorn JU, Goodman SM, Vincelette M (eds) Biodiversity, ecology, and conservation of littoral ecosystems in southeastern Madagascar, Tolagnaro (Fort Dauphin). Smithsonian Institution, Washington, DC, p 247-258

Ramanamanjato JB, Ganzhorn JU (2001) Effects of forest fragmentation, introduced Rattus rattus and the role of exotic tree plantations and secondary vegetation for the conservation of an endemic rodent and a small lemur in littoral forests of southeastern Madagascar. Anim Conserv $4: 175-183$

Randriamiadamanana M (1998) Contribution au diagnostic coprologique du parasite Spirocerca lupi chez les lémuriens du Parc Botanique et Zoologique de Tsimbazaza. Mémoire d'ingéniorat, Ecole Supérieure des Sciences Agronomiques, Université d'Antananarivo

Rasambainarivo F (2008) Contribution à l'étude des parasites des lémuriens en captivité: comparaison entre deux parcs zoologiques. $\mathrm{PhD}$ thesis, Université d'Antananarivo

Rogers WP, Sommerville RI (1963) The infective stage of nematode parasites and its significance in parasitism. Adv Parasitol 1:109-177

Schad J, Sommer S, Ganzhorn JU (2004) MHC variability of a small lemur in the littoral forest fragments of southeastern Madagascar. Conserv Genet 5:299-309

Schad J, Ganzhorn JU, Sommer S (2005) Parasite burden and constitution of major histocompatibility complex in the

Editorial responsibility: Anna Nekaris,

Oxford, UK
Malagasy mouse lemur, Microcebus murinus. Evolution 59:439-450

Schmid J, Ganzhorn JU (2009) Optional strategies for reduced metabolism in gray mouse lemurs. Naturwissenschaften 96:737-741

Schwensow N, Fietz J, Dausmann KH, Sommer S (2007) Neutral versus adaptive genetic variation in parasite resistance: importance of major histocompatibility complex supertypes in a free-ranging primate. Heredity 99: 265-277

Sloss MW, Kemp RL, Zajak A (1994) Veterinary clinical parasitology. Iowa State University Press, Ames, IA

Stear MJ, Bishop SC, Doligalska M, Duncan JL and others (1995) Regulation of egg production, worm burden, worm length and worm fecundity by host responses in sheep infected with Ostertagia circumcincta. Parasite Immunol $17: 643-652$

Stuart MD, Strier KB (1995) Primates and parasites: a case for a multidisciplinary approach. Int J Primatol 15:577-593

Taraschewski H (2006) Parasiten und Wirte als Bestandteile von Ökosystemen. In: Hiepe T, Lucius R, Gottstein B (eds) Allgemeine Parasitologie mit den Grundzügen der Immunologie, Diagnostik und Bekämpfung. Parey, Stuttgart, p 276-322

Thorne ET, William ES, Spraker TR, Helms W, Segerstrom T (1988) Bluetongue in free-ranging pronghorn antelope (Antilocapra americana) in Wyoming: 1976 and 1984. J Wildl Dis 24:113-119

Vincelette M, Dumouchel J, Giroux J, Heriarivo R (2007a) The Tolagnaro (Fort Dauphin) region: a brief overview of the geology, hydrology, and climatology. In: Ganzhorn JU, Goodman SM, Vincelette M (eds) Biodiversity, ecology and conservation of littoral ecosystems in southeastern Madagascar, Tolagnaro (Fort Dauphin). Smithsonian Institution, Washington, DC, p 9-17

Wolfe ND, Escalante AA, Karesh WB, Kilbourn A, Spielman A, Lal AA (1998) Wild primate populations in emerging infectious disease research: the missing link. Emerg Infect Dis 4:149-158

Wright PC and others (2009) Habitat disturbance and seasonal fluctuations of lemur parasites in the rain forest of Ranomafana National Park, Madagascar. In: Chapman C, Huffman MA (eds) Primates and their parasites. Cambridge University Press, Cambridge, p 311-330

Submitted: April 16, 2009; Accepted: November 10, 2009 Proofs received from author(s): March 9, 2010 